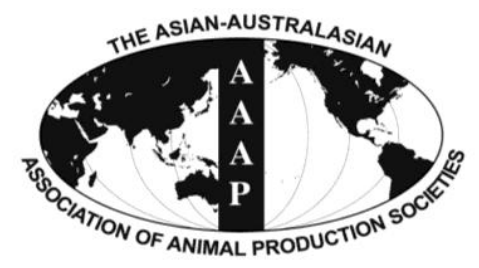

Asian Australas. J. Anim. Sci.

Vol. 26, No. 7 : 987-994 July 2013

http://dx.doi.org/10.5713/ajas.2012.12545

www.ajas.info

pISSN $1011-2367$ elSSN 1976-5517

\title{
Intestinal Development and Function of Broiler Chickens on Diets Supplemented with Clinoptilolite
}

\author{
Q. J. Wu ${ }^{1}$, Y. M. Zhou, Y. N. Wu, and T. Wang* \\ College of Animal Science and Technology, Nanjing Agricultural University, \\ No. 6, Tongwei Road, Xuanwu District, Nanjing 210095, Jiangsu, China
}

\begin{abstract}
The purpose of this study was to evaluate the effect of natural clinoptilolite (NCLI) and modified clinoptilolite (MCLI) on broiler performance, gut morphology, intestinal length and weight, and gut digestive enzyme activity. A total of $240 \mathrm{~d}$-old male chicks were randomly assigned to 3 treatments, each of which comprised 8 pens of 10 chicks per pen. Birds in the control group were fed the basal diet, while those in the experimental groups were fed diets supplemented with NCLI at $2 \%$ (NCLI group), or MCLI at $2 \%$ (MCLI group), respectively, for $42 \mathrm{~d}$. Compared with the control, supplementation with NCLI or MCLI had no significant ( $\mathrm{p}>0.05$ ) effects on productive parameters from d 1 to 42. Supplementation with NCLI or MCLI had no influence on the relative length and weight of small intestine at $\mathrm{d} 1$ to 21 . But supplementation with NCLI or MCLI significantly reduced the relative weight of duodenum. Supplementation with MCLI and NCLI was associated with greater $(\mathrm{p}<0.05)$ villus height in the jejunal and ileal mucosa compared with those areas in the controls from d 1 to 42 . However, supplementation with NCLI and MCLI had no significant ( $p>0.05$ ) influence on the crypt depth in the jejunal and ileal mucosa compared with those in the controls. The addition of either NCLI or MCLI to the diet improved the activities of total protease, and amylase in the small intestinal contents. In conclusion, supplementation with NCLI or MCLI in diets improved intestinal morphology, increased the intestinal length and weigh and gut digestive enzyme activity. (Key Words: Broiler, Clinoptilolite, Histology, Gut, Digestive Enzyme)
\end{abstract}

\section{INTRODUCTION}

Natural clinoptilolite (NCLI) is a natural zeolite, which is among the aluminosilicate materials. The aluminosilicate structure is negatively charged and attracts cations that come to reside inside the pores and channels (Mumpton and Fishman, 1977). Zeolites have large empty spaces, or cages, which can accommodate large cations, molecules and cationic groups. The basic structure of zeolites is biologically neutral, so this kind of zeolites have found diverse applications as adsorbents, ion exchangers and catalysts in industry, agriculture, veterinary medicine, sanitation and environmental protection. They are also used as a feed additive (Mumpton and Fishman, 1977; Mumpton, 1999; Martin-Kleiner et al., 2001).

Data support a favorable situation for potential applications in animal feeding. Numerous studies were

\footnotetext{
* Corresponding Author: T. Wang. Tel: +86-025-84395314, Fax: +86-025-84395314, E-mail: hdzwqj@163.com

${ }^{1}$ College of Animal Science and Technology, Henan University of Science and Technology, Luoyang 471003, Henan, China. Submitted Oct. 3, 2012; Accepted Dec. 26, 2012; Revised Mar. 23, 2013
}

shown that added CLI as a dietary supplement to the rations of cattle, pigs and poultry frequently were resulted in beneficial weight gains and less subject to disease, and show regular digestions, as well as an increase in appetite of animal. Because zeolites can slows the passage rate of digesta through the digestive tract and controls the release of nutrients in the gut (Evans, 1993; Olver, 1997; Papaioannou et al., 2002). On the other hand, zeolite's primary values are as growth promoters and carriers of a number of macro- and microchemical elements which are necessary for the vital activity of living organisms (such as vitamins; minerals, antibiotics and other active compounds). As growth promotoers zeolites appear to act as a buffer in the animals digestive system, storing nitrogen in the form of ammonium and releasing it gradually by ion exchange with zeolite (Maeda and Nosé, 1999). And the microelements present in zeolite, like calcium, potassium, sodium, as well as the majority of microelements can enhanced mineral metabolism, increased the content of macro- $(\mathrm{Ca}, \mathrm{K}, \mathrm{Na})$ and microelements in the tissues and the organs. Due to the presence of these elements, which are capable of getting involved in the exchange, the ion composition of the chyme 
changes, which normalizes the $\mathrm{pH}$ and optimizes the activity of digestive enzymes, favorable effect on feed components hydrolysis over a wider range of $\mathrm{pH}$, improved energy and protein retention (Cabezas et al., 1991; Shadrin, 1998; Parisini et al., 1999; Teimuraz et al., 2009). It is also possible that CLI remove toxins and create changes in enzymology and immunological responses (Oguz, 2011).

Similar effects were observed with some synthetic zeolites. Zeolites $\mathrm{NaX}, \mathrm{NaY}, \mathrm{NaA}$, and $\mathrm{CaA}$ were evaluated in vitro for their ability to protect animal against the effects caused by bacteria or toxins, and further improving animal growth performance by enhancing nutrient absorption in cows, lambs, pigs and laying hens (Pond, 1995; Olver, 1997; Miazzo et al., 2000; Heather et al., 2009). However, further studies are needed to investigate the effect of CLI specifically on gut morphology, gut development and gut digestive enzyme activity in broilers.

It is well known that NCLI and modified CLI (MCLI) can affect the nutrient absorption and animal growth performance. Enterocyte enzymatic activity, structure and development are the most important features of the intestinal mucosal physiology. However, no information is available regarding the effect of adding NCLI and MCLI to broiler diets on the intestinal morphology. Based on this concept, the aim of the study is to evaluate the impact of dietary supplementation with these compounds, to test whether they also have an overall beneficial effect on broiler growth performance gut morphology, gut development and gut digestive enzyme activity of broiler chickens.

\section{MATERIALS AND METHODS}

\section{Birds, housing and diets}

A total of 240 d-old Arbor Acres male broiler chicks were allocated to three dietary treatments in a randomized complete block design for $42 \mathrm{~d}$, each of which was replicated three times with 10 broilers per replicate. The dietary treatments were: i) basal diet, ii) basal diet+2\% NCLI, iii) basal diet+2\% MCLI. All birds were housed in wire cages in a 3-level battery, and housed in pens of identical size $(1.75 \times 6 \mathrm{~m})$ in a deep litter system.

All the procedures were approved by the Institutional Animal Care and Use Committee of the Nanjing Agricultural University. Birds were housed in an environmentally controlled room. The initial temperature of $32^{\circ} \mathrm{C}$ was gradually reduced according to the age of the birds, reaching $20^{\circ} \mathrm{C}$ at the end of the experiment. The lighting cycle was $24 \mathrm{~h}$ from 1 to $3 \mathrm{~d}$ of age, $18 \mathrm{~h}$ from 4 to $20 \mathrm{~d}$ of age, $21 \mathrm{~h}$ from 21 to $35 \mathrm{~d}$ of age, and $23 \mathrm{~h}$ from 35 to $42 \mathrm{~d}$ of age.

The basal diets were of the maize-soya bean type.
Broilers were fed a starter diet from d 1 to 21 and a grower diet from d 22 to 42 (Table 1). The diets were formulated in accordance with the NRC (1994) guidelines to meet the nutrient requirements of broilers. Diet compositions are shown in Table 3. Fresh diets were prepared once a week and were stored in sealed bags at $4^{\circ} \mathrm{C}$.

The NCLI used in this study was collected from the Center of China Geological Survey (Nanjing). The grainsize distributions for the samples studied were 0.15 to 0.2 $\mathrm{mm}$. For modification of natural CLI, the starting material was calcined in a muffle oven at $400^{\circ} \mathrm{C}$ for $4 \mathrm{~h}$, and formic acid was gently stirred in to ensure good dispersion. The mixture was repeatedly washed with deionized water. After stirring, the sample was allowed to settle. The sediment was oven-dried at $65^{\circ} \mathrm{C}$ for $2 \mathrm{~h}$, then ground in an agate mortar and sieved through a 100 -mesh.

\section{Performance and the length and weight of intestinal segments}

During the overall experimental period, weights of chicks were measured weekly. Feed supplied and feed leftover were weighed on the same days as above, to calculate the feed intake (FI) and feed/gain ratio (F/G).

Table 1. Formulation and calculated composition of broiler diets (on fed basis)

\begin{tabular}{lcc}
\hline Item & $1-21 \mathrm{~d}$ & $22-42 \mathrm{~d}$ \\
\hline Ingredients (\%) & 59.1 & 64.3 \\
Maize & 30.6 & 24.3 \\
Soybean meal & 3.8 & 4.5 \\
Corn gluten meal & 1.7 & 2.5 \\
Lard & 1.31 & 1.23 \\
Limestone & 1.77 & 1.58 \\
Dicalcium phosphate & 0.42 & 0.33 \\
Sodium chloride & 0.15 & 0.16 \\
L-lysine & 0.15 & 0.1 \\
DL-methionine & 1 & 1 \\
Premix* & & \\
Calculation of nutrients & 12.27 & 12.77 \\
Apparent metabolism energy (MJ/kg ) & 21.2 & 19.3 \\
Crude protein (\%) & 1.0 & 0.91 \\
Ca (\%) & 0.43 & 0.38 \\
Available P (\%) & 1.08 & 0.95 \\
Lysine (\%) & 0.50 & 0.43 \\
Methionine (\%) & 0.82 & 0.73 \\
Methionine+cystine (\%)
\end{tabular}

* Premix provided per kg of diet: limestone, $3.3 \mathrm{~g}$; L-lysine $\cdot \mathrm{HCl}, 1.5 \mathrm{~g}$; Dl-methionine, $1.3 \mathrm{~g}$; VA 10,000 IU, $\mathrm{VD}_{3} 3,000 \mathrm{IU}, \mathrm{VE} 30 \mathrm{IU}$, menadione, $1.3 \mathrm{mg}$, thiamine $2.2 \mathrm{mg}$, riboflavin, $8 \mathrm{mg}$, nicotinamide 40 $\mathrm{mg}$, choline chloride $600 \mathrm{mg}$, calcium pantothenate $10 \mathrm{mg}$, pyridoxine $\mathrm{HCl}, 4 \mathrm{mg}$, biotin $0.04 \mathrm{mg}$, folic acid $1 \mathrm{mg}$; vitamin $\mathrm{B}_{12}$ (cobalamine) $0.013 \mathrm{mg}, \mathrm{Fe}$ (from ferrous sulphate) $80 \mathrm{mg}, \mathrm{Cu}$ (from copper sulphate) $8 \mathrm{mg}$, Mn (from manganese sulphate) $110 \mathrm{mg}, \mathrm{Zn}$ (Bacitracin $\mathrm{Zn}$ ), $65 \mathrm{mg}$, iodine (from calcium iodate) $1.1 \mathrm{mg}$, Se (from sodium selenite), $0.3 \mathrm{mg}$. 
Mortalities were recorded daily and were used to adjust the total number of birds by the end of $42 \mathrm{~d}$, to determine the feed intake and $F / G$ of the broilers. At the end of each experimental period ( 21 or $42 \mathrm{~d}$ ), 8 broilers per group (one bird per replicate) from each treatment were randomly selected and weighed after feed deprivation for $12 \mathrm{~h}$, were slaughtered. Then, the intestinal segments were excised. The small intestine was divided into 3 segments: duodenum (from gizzard outlet to the end of the pancreatic loop), jejunum (from the pancreatic loop to Meckel's diverticulum), and ileum (from Meckel's diverticulum to the cecum junction). The contents of the duodenum, jejunum, and ileum (aseptically) were emptied by gentle pressure, then the length and weight were recorded.

\section{Morpholoical measurement of the jejunal and ileal mucosa}

Three cross-sections for each intestinal segment (jejunum and ileum) were fixed with formalin solution and were prepared using standard paraffin embedding procedures by sectioning at $5 \mu \mathrm{m}$ thickness, and staining with hematoxylin and eosin. A total of 15 intact, welloriented crypt-villus units were measured in each type of tissue from each broiler. Villus height and crypt depth were determined using an image processing and analyzing system (version 6.0, Image-Pro Plus), and were expressed as micrometers $(\mu \mathrm{m})$.

\section{Digestive enzyme activities of intestinal contents}

The samples of duodenum, jejunum, and ileum contents $(0.2 \mathrm{~g})$ were homogenized with $4 \mathrm{ml}$ icecold saline $(0.9 \%$ $\mathrm{NaCl})$. The digesta sample were stored immediately at $-70^{\circ} \mathrm{C}$ until it be used. The small intestinal digesta samples were diluted $10 \times$, based on the sample weight, with ice-cold PBS (pH 7.0), homogenized for $60 \mathrm{~s}$, and sonicated for 1 min with three cycles at $30 \mathrm{~s}$ intervals. The sample was then centrifuged at $6,000 \mathrm{~g}$ for $15 \mathrm{~min}$ at $4^{\circ} \mathrm{C}$. The supernatants were divided into small portions and stored at $-70^{\circ} \mathrm{C}$ for assay of enzyme assays. Protease, trypsin, chymotrypsin and amylase were measured according to the methods described by Lhoste et al. (1993).

\section{Statistical analysis}

Analyses of variance were performed using the General Linear Model procedure of statistical package for social sciences 18.0 (SPSS Inc., Chicago, IL, USA) as a completely randomized design. Results are presented as mean \pm standard error of the mean (SEM). The significant differences among different treatment means were investigated using Duncan's new multiple range test. Effects were considered significant at $\mathrm{p}<0.05$.

\section{RESULTS AND DISCUSSION}

\section{Effects of NCLI (2\%) and MCLI (2\%) on the growth performance of broilers}

The effects of the dietary treatments on broiler chicks' feed intake, average body weight gain (BWG), and F/G data in the periods of starter, grower, and the whole trial are presented in Table 2. It can be seen that no significant differences were observed between treatments from 1 to 42 d.

In the present study, the results presented in Table 2 show that adding NCLI and MCLI to the diets of broilers from 1 to $42 \mathrm{~d}$ of age produced no significant differences in terms of BWG, F/G. These findings are in agreement with

Table 2. Effects of NCLI (2\%) and MCLI (2\%) on the growth performance of broilers

\begin{tabular}{|c|c|c|c|c|c|}
\hline \multirow{2}{*}{ Item $^{1}$} & \multicolumn{3}{|c|}{ Diet treatments } & \multirow{2}{*}{ SEM } & \multirow{2}{*}{$\mathrm{p}$ value } \\
\hline & Control $^{3}$ & $\mathrm{NCLI}^{3}$ & $\mathrm{MCLI}^{3}$ & & \\
\hline \multicolumn{6}{|l|}{$\mathrm{BWG}^{2}(\mathrm{~kg})$} \\
\hline 1 to $21 \mathrm{~d}$ & 0.542 & 0.551 & 0.564 & 0.011 & 0.976 \\
\hline 22 to $42 \mathrm{~d}$ & 1.392 & 1.421 & 1.435 & 0.017 & 0.432 \\
\hline 1 to $42 \mathrm{~d}$ & 1.934 & 1.972 & 1.999 & 0.015 & 0.831 \\
\hline \multicolumn{6}{|l|}{$\mathrm{FI}^{2}(\mathrm{~g} / \mathrm{bird} / \mathrm{d})$} \\
\hline 1 to $21 \mathrm{~d}$ & 41.12 & 40.97 & 40.83 & 0.786 & 0.765 \\
\hline 22 to $42 \mathrm{~d}$ & 130.85 & 129.87 & 128.01 & 1.235 & 0.798 \\
\hline 1 to $42 \mathrm{~d}$ & 171.97 & 170.84 & 168.84 & 2.034 & 0.874 \\
\hline \multicolumn{6}{|l|}{$\mathrm{F}: \mathrm{G}^{2}$} \\
\hline 1 to $21 \mathrm{~d}$ & 1.593 & 1.560 & 1.519 & 0.034 & 0.792 \\
\hline 22 to $42 \mathrm{~d}$ & 1.974 & 1.918 & 1.873 & 0.036 & 0.823 \\
\hline 1 to $42 \mathrm{~d}$ & 1.867 & 1.819 & 1.774 & 0.021 & 0.715 \\
\hline
\end{tabular}

${ }^{1}$ Data represent means from 8 replicates per treatment, SEM $=$ Standard error of mean.

${ }^{2} \mathrm{BWG}=$ Body weight gain; FI = Feed intake; F/G = Feed intake/BW gain.

${ }^{3}$ Control $=$ Basal diet; NCLI = Basal diet supplemented with $2 \%$ natural Clinoptilolite; MCLI = Basal diet supplemented with $2 \%$ formic acid modified clinoptilolite. 
those of Evans (1989), who concluded from several experiments that CLI had no consistent beneficial effects. Similarly, the lack of response exhibited by BWG with CLI supplementation concurs with previous reports by Olver (1989), Elliot and Edwards (1991) and Zhou (2008). But some researchers reported that the supplementation of CLI to the diet improves the health status and body weight gain as well as feed efficiency of the animals (Ly et al., 2007). The expected effects of zeolites (CLI) may exhibit variation due to such factors as nature, purity, concentration, particle distribution, the CLI content of the zeolite and formulation composition in the diet. Moreover, Shariatmadari (2008) consider as this phenomenadepending on the aims and objectives of the experimental programme.

No effects of diet on mortality were detected in the present study. These findings suggested that further research regarding CLI as a feed additive is required. Numerous reports indicated that CLI is harmless, by including CLI into mixed feed; it is well tolerated by the animals and improves the production characteristics of broilers (Elliot and Edwards, 1991; Trckova et al., 2004).

Effects of NCLI and MCLI on the relative length, weights of intestine and morphology $(\mu \mathrm{m})$ of intestinal mucosa in broilers

The effects of dietary NCLI and MCLI on the relative length and weight of small intestine in broilers are shown in Table 3. Broilers were pretreated with NCLI or MCLI, there was no dietary effect on the relative length and weight of duodenum, jejunum and ileum ( $p>0.05)$ in the period of 1 to 21. Moreover, there was no significant influence on the relative length of duodenum and ileum ( $p>0.05)$, and the relative weights of ileum ( $p>0.05$ ) in the period of 22 to 42 . When broilers were treated with MCLI, the relative length and weight of jejunum were significant increased $(\mathrm{p}<0.05)$. However, the relative weight of duodenum in the NCLI group were significantly lower than the control group and the MCLI group ( $p<0.05)$, and those of the MCLI group were significantly lower than the control group $(p<0.05)$.

Morphological measurements of jejunal and ileal mucosae are presented in Table 4. During the overall experimental period the villus height in the jejunal mucosa in the MCLI group were higher $(\mathrm{p}<0.05)$ than those of the control group and NCLI group. The villus heights in the jejunal mucosa in the NCLI group were greater $(p<0.05)$ than those in the control group, but they were lower $(\mathrm{p}<0.05)$ than in the MCLI group. The villus height in the ileal mucosae of chicks receiving the NCLI and MCLI in the feed was significantly greater than in the control group $(p<0.05)$, but there were no significant differences between the two groups $(p>0.05)$ during the overall experimental period. Supplementation with NCLI and MCLI had no significant $(p>0.05)$ influence on the crypt depth in the jejunal and ileal mucosa compared with the controls during the overall experimental period. During the overall experimental period, the MCLI-supplemented group

Table 3. Effects of NCLI (2\%) and MCLI (2\%) on the relative length $(\mathrm{cm} / \mathrm{kg})$ and relative weights $(\mathrm{g} / \mathrm{kg})$ of small intestine in broilers

\begin{tabular}{|c|c|c|c|c|c|}
\hline \multirow{2}{*}{ Items $^{1}$} & \multicolumn{3}{|c|}{ Diet treatments } & \multirow{2}{*}{ SEM } & \multirow{2}{*}{$\mathrm{p}$ value } \\
\hline & Control $^{2}$ & $\mathrm{NCLI}^{2}$ & $\mathrm{MCLI}^{2}$ & & \\
\hline \multicolumn{6}{|l|}{1 to $21 \mathrm{~d}$} \\
\hline \multicolumn{6}{|l|}{ Relative length } \\
\hline Duodenum & 34.47 & 31.55 & 31.05 & 0.84 & 0.206 \\
\hline Jejunum & 73.50 & 74.26 & 73.60 & 0.69 & 0.980 \\
\hline Ileum & 67.71 & 69.63 & 70.74 & 0.63 & 0.606 \\
\hline \multicolumn{6}{|c|}{ Relative weights } \\
\hline Duodenum & 9.52 & 8.62 & 8.59 & 0.29 & 0.347 \\
\hline Jejunum & 14.67 & 15.35 & 15.87 & 0.37 & 0.433 \\
\hline Ileum & 10.34 & 10.73 & 11.10 & 0.22 & 0.384 \\
\hline \multicolumn{6}{|l|}{22 to $42 \mathrm{~d}$} \\
\hline \multicolumn{6}{|l|}{ Relative length } \\
\hline Duodenum & 11.27 & 10.71 & 10.59 & 0.39 & 0.769 \\
\hline Jejunum & $25.04^{\mathrm{a}}$ & $24.44^{\mathrm{a}}$ & $29.54^{\mathrm{b}}$ & 0.94 & 0.042 \\
\hline Ileum & 28.70 & 28.17 & 31.97 & 0.85 & 0.140 \\
\hline \multicolumn{6}{|c|}{ Relative weights } \\
\hline Duodenum & $7.61^{\mathrm{a}}$ & $3.95^{\mathrm{b}}$ & $5.34^{\mathrm{c}}$ & 0.43 & 0.002 \\
\hline Jejunum & $8.44^{\mathrm{a}}$ & $8.37^{\mathrm{a}}$ & $10.56^{\mathrm{b}}$ & 0.41 & 0.036 \\
\hline Ileum & 8.05 & 7.93 & 9.03 & 0.22 & 0.079 \\
\hline
\end{tabular}


Table 4. Effects of NCLI (2\%) and MCLI (2\%) on the morphology $(\mu \mathrm{m})$ of the intestinal mucosa in broilers

\begin{tabular}{|c|c|c|c|c|c|}
\hline \multirow{2}{*}{ Items } & \multicolumn{3}{|c|}{ Diet treatments } & \multirow{2}{*}{ SEM } & \multirow{2}{*}{$\mathrm{p}$ value } \\
\hline & Control $^{2}$ & $\mathrm{NCLI}^{2}$ & $\overline{\mathrm{MCLI}^{2}}$ & & \\
\hline \multicolumn{6}{|l|}{1 to $21 \mathrm{~d}$} \\
\hline \multicolumn{6}{|l|}{ Jejunum } \\
\hline Villus height $(\mu \mathrm{m})$ & $818.78^{\mathrm{a}}$ & $904.96^{\mathrm{b}}$ & $969.35^{\mathrm{c}}$ & 12.62 & 0.002 \\
\hline Crypt depth $(\mu \mathrm{m})$ & 123.00 & 114.17 & 106.03 & 3.80 & 0.194 \\
\hline Villus height:crypt depth & $6.66^{\mathrm{a}}$ & $7.93^{\mathrm{ab}}$ & $9.16^{\mathrm{b}}$ & 0.31 & 0.003 \\
\hline \multicolumn{6}{|l|}{ Ileum } \\
\hline Villus height $(\mu \mathrm{m})$ & $517.83^{\mathrm{a}}$ & $549.32^{\mathrm{b}}$ & $570.76^{\mathrm{b}}$ & 6.21 & 0.001 \\
\hline Crypt depth $(\mu \mathrm{m})$ & 131.49 & 118.74 & 105.06 & 5.68 & 0.166 \\
\hline Villus height:crypt depth & $3.95^{\mathrm{a}}$ & $4.66^{\mathrm{ab}}$ & $5.45^{\mathrm{b}}$ & 0.23 & 0.012 \\
\hline \multicolumn{6}{|l|}{22 to $42 \mathrm{~d}$} \\
\hline \multicolumn{6}{|l|}{ Jejunum } \\
\hline Villus height $(\mu \mathrm{m})$ & $1,054.94^{\mathrm{a}}$ & $1,193.63^{\mathrm{b}}$ & $1,344.99^{c}$ & 14.69 & 0.001 \\
\hline Crypt depth $(\mu \mathrm{m})$ & 146.44 & 134.53 & 121.22 & 4.75 & 0.091 \\
\hline Villus height:crypt depth & $7.21^{\mathrm{a}}$ & $8.88^{\mathrm{ab}}$ & $10.13^{\mathrm{b}}$ & 0.38 & 0.001 \\
\hline \multicolumn{6}{|l|}{ Ileum } \\
\hline Villus height $(\mu \mathrm{m})$ & $789.49^{\mathrm{a}}$ & $844.64^{\mathrm{b}}$ & $902.55^{\mathrm{b}}$ & 9.27 & 0.002 \\
\hline Crypt depth $(\mu \mathrm{m})$ & 148.44 & 128.55 & 125.13 & 4.27 & 0.051 \\
\hline Villus height:crypt depth & $5.32^{\mathrm{a}}$ & $6.57^{\mathrm{ab}}$ & $7.21^{\mathrm{b}}$ & 0.23 & 0.001 \\
\hline
\end{tabular}

${ }^{1}$ Data represent means from 8 replicates per treatment, $\mathrm{SEM}=$ Standard error of mean.

${ }^{2}$ Control = Basal diet; NCLI = Basal diet supplemented with $2 \%$ natural Clinoptilolite; MCLI = Basal diet supplemented with $2 \%$ formic acid modified clinoptilolite.

${ }^{3}$ Means with different superscript letters in the same line differ significantly; Lowercases represent $\mathrm{p}<0.05$.

differed significantly from the control group in terms of the villus height to crypt depth ratio in the jejunal and ileal mucosa $(\mathrm{p}<0.05)$. The villus height to crypt depth ratio in the NCLI group was not significantly different from either the control group or the MCLI group ( $\mathrm{p}>0.05)$.

The present study showed change in the relative weight of the jejunum in birds fed with NCLI or MCLI supplemented diet $(p<0.05)$. These may be associated with slower passage of ingest through the digestive tract, and the jejunum utilized the limited nutrients for its growth with higher priority over body weight increase. Greater villus heights in the jejunal and ileal mucosa indicate that the function of the intestinal villi was increased (Ruttanavut and Yamauchi, 2010). In the present study, increases were observed in villus height and villus height to crypt depth ratio in the small intestinal mucosa of the broiler chicks supplemented with NCLI and MCLI. These results are in agreement with the findings of Tatar et al. (2008), who suggest that zeolite can stimulate villi of the small intestine. Such improvement in the morphology of the intestinal mucosa may be explained by the lower numbers of $E$. coli and Salmonella. It is reported that NCLI, a mucus stabilizer, effectively acts by attaching to the mucus to reinforce the intestinal mucosal barrier, and helps in the regeneration of the epithelium, therefore reducing intestinal colonization and infectious processes. This ultimately decreases inflammatory processes at the intestinal mucosa, thus increasing villus height and secretory activity (Loddi et al., 2004). Furthermore, increased villus size was also associated with activated cell proliferation in the crypt (Lauronen et al., 1998). In conclusion, the present results and related literature suggested that these intestine morphological changes might be induced by improved jejumum and ileum lumen due to adsorptive function of the crystal structural cavities of CLI (Khambualai et al., 2009), because a crystal structure of CLI is thought to induce epithelial cell generation in broilers (Mumpton and Fishman, 1977).

Effects of NCLI (2\%) and MCLI (2\%) on the activities of digestive enzymes of the intestinal contents in broilers (U/g)

As shown in Table 5, NCLI and MCLI had an effect on digestive enzyme activities of duodenum content. Markedly increased activities of digestive enzyme including protease, chymotrypsin, trypsin and amylase in the small intestinal contents were observed in the NCLI and MCLI-treated groups during the overall experimental period $(\mathrm{p}<0.05)$.

In the present experiment, supplementation with NCLI and MCLI could significant improved the activities of the digestive enzymes in the small intestinal contents $(p<0.05)$. Our results were consistent with the previous studies of the clay minerals. It has been reported that the addition of clay to the feedstuffs improved the nutrient digestibility and the 
Table 5. Effects of NCLI (2\%) and MCLI (2\%) on the activities of digestive enzymes of the intestinal contents in broilers (U/g)

\begin{tabular}{|c|c|c|c|c|c|}
\hline \multirow{2}{*}{ Items $^{1}$} & \multicolumn{3}{|c|}{ Diet treatments } & \multirow{2}{*}{ SEM } & \multirow{2}{*}{$\mathrm{p}$ value } \\
\hline & Control $^{2}$ & $\mathrm{NCLI}^{2}$ & $\mathrm{MCLI}^{2}$ & & \\
\hline \multicolumn{6}{|l|}{1 to $21 \mathrm{~d}$} \\
\hline \multicolumn{6}{|l|}{ Duodenum } \\
\hline Amylase & $446.09^{\mathrm{a}}$ & $632.27^{b}$ & $645.23^{\mathrm{b}}$ & 20.03 & 0.002 \\
\hline Trypsin & $4.38^{\mathrm{a}}$ & $5.47^{\mathrm{b}}$ & $5.83^{\mathrm{b}}$ & 0.14 & 0.001 \\
\hline Chymotrypsin & $5.23^{\mathrm{a}}$ & $6.23^{\mathrm{b}}$ & $6.50^{\mathrm{b}}$ & 0.64 & 0.000 \\
\hline Protease & $6.84^{\mathrm{a}}$ & $8.21^{\mathrm{b}}$ & $8.62^{\mathrm{b}}$ & 0.89 & 0.001 \\
\hline \multicolumn{6}{|l|}{ Jejumum } \\
\hline Amylase & $468.35^{\mathrm{a}}$ & $576.88^{b}$ & $620.75^{b}$ & 15.20 & 0.002 \\
\hline Trypsin & $5.11^{\mathrm{a}}$ & $6.53^{b}$ & $6.88^{\mathrm{b}}$ & 0.18 & 0.001 \\
\hline Chymotrypsin & $5.93^{\mathrm{a}}$ & $6.85^{\mathrm{b}}$ & $7.28^{\mathrm{b}}$ & 0.15 & 0.003 \\
\hline Protease & $7.07^{\mathrm{a}}$ & $8.59^{\mathrm{b}}$ & $9.08^{\mathrm{b}}$ & 0.21 & 0.001 \\
\hline \multicolumn{6}{|l|}{ Ileum } \\
\hline Amylase & $462.78^{\mathrm{a}}$ & $546.48^{\mathrm{b}}$ & $552.61^{\mathrm{b}}$ & 11.48 & 0.001 \\
\hline Trypsin & $4.89^{\mathrm{a}}$ & $6.19^{\mathrm{b}}$ & $6.31^{\mathrm{b}}$ & 0.18 & 0.002 \\
\hline Chymotrypsin & $5.73^{\mathrm{a}}$ & $6.91^{\mathrm{b}}$ & $7.14^{\mathrm{b}}$ & 0.15 & 0.001 \\
\hline Protease & $6.88^{\mathrm{a}}$ & $8.37^{\mathrm{b}}$ & $8.49^{\mathrm{b}}$ & 0.22 & \\
\hline \multicolumn{6}{|l|}{22 to $42 \mathrm{~d}$} \\
\hline \multicolumn{6}{|l|}{ Duodenum } \\
\hline Amylase & $422.82^{\mathrm{a}}$ & $465.15^{\mathrm{b}}$ & $479.48^{b}$ & 7.37 & 0.001 \\
\hline Trypsin & $5.35^{\mathrm{a}}$ & $6.12^{\mathrm{b}}$ & $6.26^{\mathrm{b}}$ & 0.11 & 0.001 \\
\hline Chymotrypsin & $5.47^{\mathrm{a}}$ & $7.16^{\mathrm{b}}$ & $6.83^{\mathrm{b}}$ & 0.17 & 0.002 \\
\hline Protease & $7.02^{\mathrm{a}}$ & $8.35^{\mathrm{b}}$ & $8.94^{\mathrm{b}}$ & 0.19 & 0.002 \\
\hline \multicolumn{6}{|l|}{ Jejumum } \\
\hline Amylase & $439.59^{\mathrm{a}}$ & $586.26^{\mathrm{b}}$ & $601.60^{\mathrm{b}}$ & 16.52 & 0.001 \\
\hline Trypsin & $5.31^{\mathrm{a}}$ & $6.23^{\mathrm{b}}$ & $6.28^{\mathrm{b}}$ & 0.12 & 0.001 \\
\hline Chymotrypsin & $6.12^{\mathrm{a}}$ & $7.18^{\mathrm{b}}$ & $7.19^{b}$ & 0.13 & 0.012 \\
\hline Protease & $7.14^{\mathrm{a}}$ & $8.29^{b}$ & $8.53^{\mathrm{b}}$ & 0.23 & 0.002 \\
\hline \multicolumn{6}{|l|}{ Ileum } \\
\hline Amylase & $436.74^{\mathrm{a}}$ & $535.62^{b}$ & $554.78^{b}$ & 13.13 & 0.007 \\
\hline Trypsin & $5.30^{\mathrm{a}}$ & $6.73^{b}$ & $6.96^{\mathrm{b}}$ & 0.18 & 0.001 \\
\hline Chymotrypsin & $6.09^{\mathrm{a}}$ & $7.01^{\mathrm{b}}$ & $7.22^{\mathrm{b}}$ & 0.14 & 0.002 \\
\hline Protease & $7.25^{\mathrm{a}}$ & $8.86^{\mathrm{b}}$ & $8.99^{\mathrm{b}}$ & 0.21 & 0.006 \\
\hline
\end{tabular}

${ }^{1}$ Data represent means from 8 replicates per treatment, SEM $=$ Standard error of mean.

${ }^{2}$ Control $=$ Basal diet; NCLI $=$ Basal diet supplemented with $2 \%$ natural Clinoptilolite; MCLI = Basal diet supplemented with $2 \%$ formic acid modified clinoptilolite.

${ }^{3}$ Means with different superscript letters in the same line differ significantly; Lowercases represent $\mathrm{p}<0.05$.

enzymatic activity of gastrointestinal secretions (Cabezas et al., 1991; Ouhida et al., 2000; Alzueta et al., 2002; Hu et al., 2004). Because, the ion-exchange properties of the zeolite could alter the $\mathrm{pH}$ and increase the content of macro- $(\mathrm{Ca}, \mathrm{K}$, $\mathrm{Na}$ ) and microelements in the gastrointestinal fluids (Teimuraz et al., 2009), thereby changing the enzymatic activity of gastrointestinal secretions (Martin-Kleiner et al., 2001). Moreover, some reports indicate that the villi and microvilli of intestinal mucosa can affect the secretion of digestive enzymes (Gao, 1998). In the present study, increases in villus height and villus height:crypt depth ratio were observed in the small intestinal mucosa of chicks supplemented with NCLI and MCLI. Such improved intestinal mucosal morphology may be explained by the higher enzymatic activity of gastrointestinal contents.

From this study, the following conclusion can be drawn. The supplementation of NCLI and MCLI into the diets of broiler chicks can exert beneficial effect in the gut morphology, gut development and gut digestive enzyme activity. But the mechanism(s) of CLI on the gastrointestinal tract has not yet been studied. Thus, NCLI and MCLI can be beneficial as a feed additive in the broilers diet, and there is a need for further research to understand and clarify the mechanism(s) involved.

\section{ACKNOWLEDGEMENTS}

This research was supported by a project funded by the 
priority academic program development of Jiangsu higher education institutions.

\section{REFERENCES}

Alzueta, C., L. T. Ortiz, A. Rebole, M. L. Rodriguez, C. Centeno, and J. Trevino. 2002. Effects of removal of mucilage and enzyme or sepiolite supplement on the nutrient digestibility and metabolyzable energy of a diet containing linseed in broiler chickens. Anim. Feed Sci. Technol. 97:169-181.

Cabezas, M. J., D. Salvador, and J. V. Sinisterra. 1991. Stabilisation-activation of pancreatic enzymes adsorbed on to a sepiolite clay. J. Chem. Tech. Biotechnol. 52:265-274.

Elliot, M. A., and H. M. Edwards. 1991. Comparison on the effects of synthetic and natural zeolite on laying hen and broiler chicken performance. Poult. Sci. 70:2115-2130.

Evans, M. 1993. Investigations into the practical applications of zeolites in diets for poultry. PhD Thesis University of New England.

Evans, M. 1989. Zeolites- Do they have a role in poultry production. In: Recent Advances in Animal Nutrition in Australia (Ed. D. J. Farrell), Armidale. University of New England. 249-268.

Gao, L. S. 1998. (In Chinese) in Digestive Physiology and Health Protection. Curatorial Science and Technology Press. Beijing. 173-230.

Heather, A. R., K. Olson, P. Johnson, and C. Wright. 2009. Clinoptilolite as a supplement to reduce the toxic: effects of High-Sulfate Water. 62nd Society for Range Management Annual Meeting Paper. No 2030-18.

Hu, C. H., M. S. Xia, Z. R. Xu, and L. Xiong. 2004. Effects of copper-bearing montmorillonite on growth performance and digestive function of growing pigs. Asian-Aust. J. Anim. Sci. 17:1575-1581.

Khambualai, O., J. Ruttanavut, M. Kitabatake, H. Goto, T. Erikawa, and K. Yamauchi. 2009. Effects of dietary natural zeolite including plant extract on growth performance and intestinal histology in Aigamo ducks. Br. Poult. Sci. 50:123130.

Lauronen, J., M. P. Pakarinen, P. Kuusanmaki, E. Savilahti, P. Vento, T. Paavonen, and J. Halttunen. 1998. Intestinal adaptation after massive proximal small-bowel resection in the pig. Scand. J. Gastroenterol. 33:152-158.

Lhoste, E. F., M. Fiszlewicz, A. M. Gueugneau, C. WickerPlanquart, A. Puigserver, and T. Corring. 1993. Effects of dietary proteins on some pancreatic mRNAs encoding digestive enzymes in the pig. J. Nutr. Biochem. 4:143-152.

Loddi, M. M., V. M. B. Maraes, I. S. O. Nakaghi, F. Tucci, Mi. Hannas, and J. A. Ariki. 2004. Mannan oligosaccharide and organic acids on performance and intestinal morphometric characteristics of broiler chickens. In proceedings of the 20th annual symposium. (Supplement) 1: 45.

Ly, J., F. Grageola, C. Lemus, and M. Castrp. 2007. Ileal and rectal digestibility of nutrients in diet based on leucaena for pigs, influence of the inclusion zeolite. J. Anim. Vet. Adv. 6:13711376.

Maeda, T., and Y. Nosé. 1999. A new antibacterial agent: Antibacterial Zeolite. Artificial. Organs. 23:129-130.
Martin-Kleiner, I., Z. Flegar-Meštrić, R. Zadro, D. Breljak, S. Janda, S. Stojković., R. M. Marušić, M. Radačić, and M. Boranić. 2001. The effect of the zeolite clinoptilolite on serum chemistry and hematopoiesis in mice. Food. Chem. Toxicol. 39:717-727.

Miazzo, R., C. A. R. Rosa, E. C. D. Q. Cavalho, C. Magnoli, S. M. Chiacchiera, G. Palacio, M. Saenz, A. Kikot, E. Basaldella, and A. Dalcero. 2000. Efficacy of synthetic zeolite to reduce the toxicity of aflatoxin in broiler chicks. Poult. Sci. 79:1-6.

Mumpton, F. A. 1999. La roca magica: Uses of natural zeolites in agriculture and industry. Proceedings of the National Academy of Sciences of the USA. 96:3463-3470.

Mumpton, F. A., and P. H. Fishman. 1977. The application of natural zeolites in animal science and aquaculture. J. Anim. Sci. 45:1188-1203.

Oguz, H. 2011. A review from experimental trials on detoxification of aflatoxin in poultry feed. Eurasian. J. Vet. Sci. 27:1-12.

Olver, M. D. 1997. Effect of feeding clinoptilolite (zeolite) on the performance of 3 strains of laying hens. Br. Poult. Sci. 38: 220-222.

Olver, M. D. 1989. Effect of feeding Clinoptilolite (zeolite) to three strains of laying hens. Br. Poult. Sci. 30:115-121.

Ouhida, I., J. F. Perez, J. Piedrafita, and J. Gasa. 2000. The effects of sepiolite in broiler chicken diets of high, medium and low viscosity. Productive performance and nutritive value. Anim. Feed Sci. Technol. 85:183-194.

Papaioannou, D. S., S. C. Kyriakis, A. Papasteriadis, N. Roumbies, A. Yannakopoulos, and C. Alexopoulos. 2002. Effect of in-feed inclusion of a natural zeolite(clinoptilolite) on certain vitamin, macro and trace element concentrations in the blood, liver and kidney tissues of sows. Res. Vet. Sci. 72:61-68.

Parisini, P., G. Martelli, L. Sardi, and F. Escribano. 1999. Protein and energy retention in pigs fed diets containing sepiolite. Anim. Feed Sci. Technol. 79:155-162.

Pond, W. G. 1995. Zeolites in animal nutrition and health: a review. In: Natural Zeolites '93, $1^{\text {st }}$ edition (Ed. D. W. Ming and F. A. Mumpton), p: 449. International Community of Natural Zeolites,Brockport, New York.

Ruttanavut, J., and K. Yamauchi. 2010. Growth performance and histological alterations of intestinal villi in broilers fed dietary mixed minerals. Asian. J. Anim. Sci. 4:96-106.

Shadrin, A. M. 1998. Prirodnye tseolity Sibiri v zhivotnovodstve, veterinarii i okhrane okruzhayushchei sredy. Novosibirsk. 116. $\mathrm{p}$ (in Russian),

Shariatmadari, F. 2008. The application of zeolite in poultry Production. World. Poult. Sci. J. 64:76-84.

Tatar, A., F. Boldaji, B. Dastar, and A. Yaghobfar. 2008. Comparison of different levels of zeolite on serum characteristics, gut $\mathrm{pH}$, apparent digestibility of crude protein and performance of broiler chickens. International Zeolite Conference, Tehran, Iran, 235.

Teimuraz, A., P. Karaman, K. Tengiz, and L. Eprikashvili. 2009. Possibility of application of natural zeolites for medicinal purposes. Bull. Georg. Natl. Acad. Sci. 3:158-167.

Trckova, M., L. Matlova, L. Dvorska, and I. Pavlik. 2004. Kaolin, bentonite and zeolites as feed supplements for animals: Health advantages and risks. Vet. Med. 49:389-399. 
Yang, Y., P. A. Iji, A. Kocher, L. L.Mikkelsen, and M. Choct. 2007. Zhou, Y. M. 2008. Mechanism of nutritional effect and harmful Effects of mannanoligosaccharide on growth performance, the development of gut microflora, and gut function of broiler chickens raised new litter. J. Appl. Poult. Res. 16:280-288. agent reduction of natural zeolite in broilers. $\mathrm{PhD}$ thesis, Nanjing Agricultural University, China. 